\title{
MARTON, Scarlett. (org.) Nietzsche em chave hispânica. (São Paulo Edições Loyola, 2015)*
}

\author{
Gloria Luque Moya**
}

O GEN (Grupo de Estudos Nietzsche), por meio de sua coleção Sendas \& Veredas, em sua série Recepção, dirigida pela professora Scarlett Marton, com a intenção de abrir novas frentes de discussão, vem publicando uma série de números monográficos sobre a atualidade da investigação acerca de Nietzsche em diferentes países. Trata-se de acolher as distintas linhas interpretativas que na atualidade se estão levando a cabo em diferentes países com a finalidade de promover uma reflexão sobre a singularidade e especificidade de suas leituras sobre os textos de Nietzsche. Assim, por exemplo, já foram publicados os seguintes títulos: Nietzsche na Alemanha; Nietzsche abaixo do Equador: Uma recepção na América do Sul; Nietzsche pensador mediterrâneo: a recepção italiana; Nietzsche, um francês entre os franceses. E agora este volume, que trata de reunir sob o título Nietzsche em chave hispânica uma série de trabalhos de alguns dos investigadores de maior relevo na pesquisa Nietzsche que se tem feito neste momento na Espanha. Os autores que aparecem no livro são quase todos os filósofos que têm promovido na Espanha os estudos

\footnotetext{
* Este texto também será publicado na revista Estudios Nietzsche 16/2016, da Sociedade Espanhola de Estudos sobre Friedrich Nietzsche (SEDEN). Tradução de Márcio José Silveira Lima ** Professora da Universidade de Málaga, Espanha.

Correio eletrônico: glorialm@uma.es
} 
Moya, G.

sobre F. Nietzsche nas últimas duas décadas, dando um impulso de enorme importância à Nietzsche Forschung, fundando uma Sociedade espanhola de estudos sobre F. Nietzsche (SEDEN), sobre cujos auspícios se criou uma prestigiosa revista, a Estudios Nietzsche (ano 2000). Uma das contribuições mais significativas dessa sociedade, por seu alcance e sua grande utilidade para a investigação, tem sido a tradução para o espanhol, partindo das últimas correções do texto original em alemão, de grande parte dos escritos e da correspondência de F. Nietzsche: Fragmentos Póstumos (4 vols., 2007-2010, Tecnos: dir. Diego Sánchez Meca); Correspondencia (6 vols., 2005-2013, Trotta, dir. Luis Enrique de Santiago Guervós) e Obras Completas (4 vols., 2011-2016, Tecnos, dir. Diego Sánchez Meca). Essa enorme tarefa que realizaram em tão poucos anos presta certamente uma colaboração inestimável para todos aqueles estudiosos de língua hispânica que se dedicam a estudar a vida e a obra de Nietzsche. A importância dessa contribuição se pode compreender e ampliar no primeiro capítulo do livro, que revela a presença de Nietzsche na Espanha nas duas últimas décadas.

As contribuições que aparecem no livro são significativas tanto em termos de autores, ligados à SEDEN, quanto por aquilo que abordam: Marco Parmeggiani e Fernando Fava, "Nietzsche na Espanha"; Francisco Ares Doz, “Alcance e limites da recepção de Nietzsche no contexto acadêmico espanhol (1939-1975)"; Diego Sánchez Meca, "Vontade de potência e interpretação como pressupostos de todo processo orgânico" e "Nietzsche ou a eternidade do tempo"; Luis Enrique de Santiago Guervós, "A dimensao estética do jogo na filosofia de Nietzsche"; Manuel Barrios Casares, "O "giro retorico" de Nietzsche" e "Niilismo e pós-humanidade na cultura contemporânea"; Joan B. Llinares, "A filosofia da linguagem em Nietzsche"; Remedios Ávila Crespo, "A critica de Nietzsche ao romantismo"; Marco Parmegginai, "Nietzsche: o pluralismo e a pós-modernidade". Com isso, o leitor português e brasileiro têm a 
seu alcance um material importante para conhecer o trabalho que está sendo feito na Espanha, ao mesmo tempo em que se informam sobre a recepção de Nietzsche nesse país desde 1939. Desse modo se desenha um novo quadro na recepção de Nietzsche na Espanha e se apresentam aos leitores novas linhas de investigação para além daquelas com que trabalham atualmente. É indubitável que os esforços que leva a cabo o grupo GEN de São Paulo em difundir a pesquisa que se realiza em distintos países contribuem para criar um espaço comum para que a investigação de um dos pensadores mais importantes de nossa contemporaneidade tenha esse caráter universal que seguramente possibilitará um trabalho mais produtivo acerca da interpretação da vida e da obra de F. Nietzsche.

Resenha recebida para publicação em 20/03/2016.

Resenha aceita para publicação em 15/04/2016. 